https://doi.org/10.31713/m1018

\title{
STRUCTURAL BONDS DEVELOPMENT \\ IN THE BACKFILL MASS WHEN CHANGING THE DISPERSION OF THE BINDING MATERIAL
}

\author{
Petlovanyi M.V. \\ Candidate of Technical Sciences, Associate Professor, \\ Dnipro University of Technology, Ukraine
}

Zubko S.A.

Candidate of Technical Sciences, PJSC "Zaporizhzhia Iron Ore Plant”, Ukraine

Sai K.S.

Candidate of Technical Sciences, Associate Professor, Dnipro University of Technology, Ukraine

\section{Khalymendyk O.V.}

Candidate of Technical Sciences, Associate Professor, Dnipro University of Technology, Ukraine

\begin{abstract}
Purpose. Theoretical and experimental research on the structural and strength peculiarities of the backfill mass formation during the ore deposits development by activating the binding material of the backfill mixture using fine grinding at the stage of its preparation.
\end{abstract}

Methods. An integrated methodological approach is used, consisting of laboratory studies on determining the properties of backfill mixtures and the structural internal bonds of the backfill mass using scanning electron microscopy. Some laws of the binding material chemistry are used and systematized in the course of theoretical research.

Findings. Based on theoretical and experimental research, the interaction and the hydration products of the backfill mixture binding components with water have been studied. The use of a finely ground combined binding material made of slags and limestone improves and strengthens the structural bonds of the backfill mass through a large gap in the covalent bonds of silica and slags, the transition of ions of a weak ionic bond to the formation of other compounds and equalizing the ratio of $\mathrm{Si}$ and $\mathrm{Ca}$ ions in solution.

Originality. It has been determined that with an increase in the specific surface area of the binding material particles, the shape of structural new formations of the backfill mass improves, has high strength, and the basicity of its new formations increases.

Practical implications. Using the results, it is possible to rationally choose the binding material dispersion, obtain high strength of the backfill mass and increase the stability of its outcropping.

Keywords: structural bonds, backfill mass, strength, binding material, fine grinding. 


\section{Introduction}

Iron-ore industry occupies an important place in the development of Ukrainian economy, providing substantial foreign exchange earnings to the state budget. Thus, according to the State Fiscal Service of Ukraine, the export of iron-ore raw materials and concentrate in 2019 amounted to \$ 3.18 million [1,2]. About 130 million tons of iron ore are mined in Ukraine annually, of which $90 \%$ is mined by open-cut mining, and $10 \%$ - by underground mining $[3,4]$.

Intensive iron ore mining leads to considerable changes in the environment: significant cavities are formed in the rock mass, leading to the daylight surface deformations; the natural regime of ground and surface waters is disturbed; storage of waste from the mining industry and iron-ore beneficiation occupies valuable agricultural land and is a source of their pollution. About 15 million tons of iron ore are mined by underground system of mining in 9 mines, and only 1 mine uses a highly advanced, environmentally friendly technology for the extraction of iron ore with hardening backfilling [5-9].

To prevent the consequences of engineering activity for the extraction of iron ores, the implementation of work should be provided on filling the cavities with backfill mixtures consisting of various rocks, industrial processing waste, which eventually is changed into a solid state under the influence of various factors. This is performed in the case when it is necessary to completely extract iron ores due to their high value (content of $\mathrm{Fe}>60 \%$ ), and the earth's surface must be prevented from deformation.

Creating a sufficiently strong artificial mass, as close as possible to the natural strength properties of the rocks surrounding the cavity, is possible using the internal chemical transformation of the backfill mixture minerals [10]. It is important to form structural bonds in the volume of an artificially created mass to resist outcropping as a result of mining operations under the influence of impulse loads in the form of blasting operations or a stationary load from the gravitational forces of the surrounding natural rock mass. Under the influence of the forces of rock pressure and seismic loads from blasting operations, both compression and tensile stresses arise on the contour of the mined-out chamber, depending on its configuration. In this 
regard, the internal structural bonds of the backfill mass must be resistant to the indicated types of stresses, especially tensile stresses, since, as for the backfilling mass, they amount to 0.05$0.1 \sigma_{\text {compr }}[11,12]$.

Therefore, the issues of creating a strong backfill mass with internal bonds that are resistant to loads are relevant for mining enterprises that perform backfilling the underground cavities with hardening mixtures. One of the methods of significant chemical transformation and activation of hydration processes in the backfill mixture is fine grinding of the binding material, which, despite its increased energy consumption, can be cost-effective [13-15]. Moreover, some components of the backfill mixture, except for the main binding material, may have potential binding properties, improving the structure and strength of the artificial mass.

The actual influences of finely ground particles of a binding material on the properties of backfill mass are studied in this work.

\section{Purpose and objectives of research}

The purpose of this work is to study and identify the structural and strength peculiarities of the backfill mass formation when the binding material of the backfill mixture is activated by fine grinding.

To achieve the purpose set, the following research objectives are solved:

- preparing the test backfill mixtures with traditional and increased dispersion of the binding material;

- studying the transformation of the internal chemical bonds structure influenced by the dispersion of binding material.

\section{Materials and methods of research}

An integrated research method, consisting of two blocks, is used in the work: a set of laboratory studies to determine the properties of backfill mixtures, as well as physical-chemical studies of structural bonds. Some laws of the binding material chemistry are used and systematized in the course of theoretical research. This paper studies the composition of the hardening backfill mixture, which is used in the development of the Pivdenno-Bilozerske field and recommended by the Scientific-Research Mining Institute (Kryvyi Rih).

To prepare the backfill mixture, ground granulated blast-furnace slag $(17 \%)$ is used as a binding material, crushed dump rocks $(22 \%)$, flux limestone waste (44\%) and water (17\%) serve as an inert 
filler [16]. Before mixing the components, granulated blast-furnace slags are ground in Ball Mills to at least $55-60 \%$ of particles with a coarseness of $-0.074 \mathrm{~mm}$, which is equivalent to a specific surface area of $2000 \mathrm{~cm}^{2} / \mathrm{g}$. This component composition has not been studied at different values of the specific surface area of the binding material. We have revealed [17] that it is expedient to jointly grind slag and flux limestone, when preparing the binding material of the backfill mixture. Moreover, the rational amount of limestone is up to $50 \%$. Therefore, a combined binding material is considered in further research. The research objective is to study the changes in structure and strength with a 2-fold increase in the specific surface area of particles. Therefore, the backfill mass at 2000 and $4000 \mathrm{~cm}^{2} / \mathrm{g}$ is compared.

To achieve the value of specific surface area of blast-furnace slag and flux limestone particles $4000 \mathrm{~cm}^{2} / \mathrm{g}$, a laboratory gas-jet unit USI-20 is used (Fig. 1). The specific surface area of particles is determined with the help of the Tovarov device. The fraction of particles fed into the gas-jet mill should be no more than $2.5 \mathrm{~mm}$, therefore, using a laboratory sieve, the material is sifted through sieves of $-2.5 \mathrm{~mm}$.
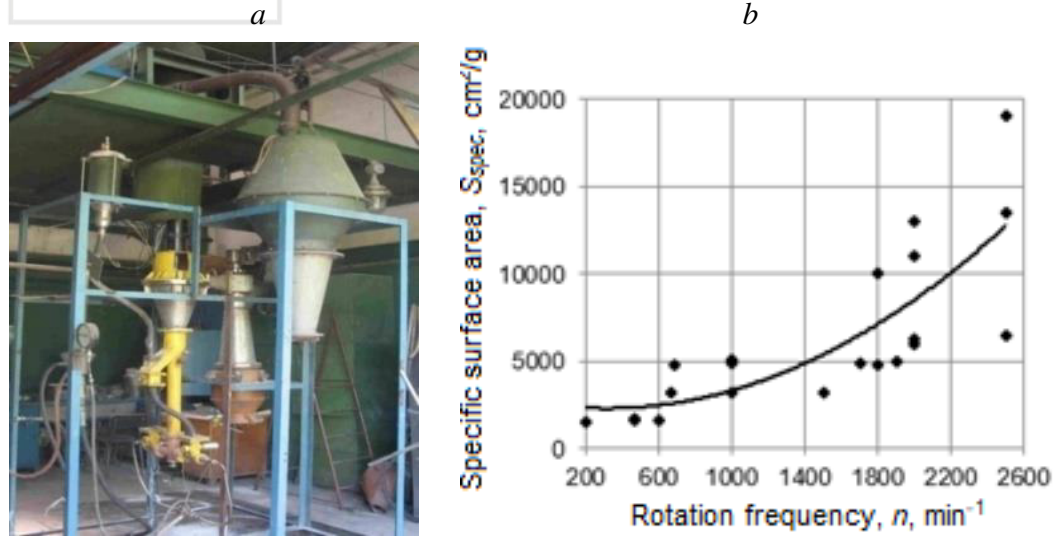

Fig. 1. Laboratory research on grinding the binding material:

(a) general view of the gas-jet unit USI-20; $(b)$ dependence of the specific surface area on the frequency of the jet mill rotation 
According to the empirical dependence [18], shown in Figure 1b, the required rotation frequency of the jet mill classifier is determined to obtain the required specific surface area. To conduct experimental research, the design basis conditions of grinding the slag and flux are given in Table 1.

Table 1

Design basis conditions of grinding the slag and limestone in a laboratory gas-jet mill

\begin{tabular}{|c|c|c|c|c|}
\hline Set of tests & Material & $P, \mathrm{MPa}$ & $n, \mathrm{~min}^{-1}$ & $S_{\text {spec }}, \mathrm{cm}^{2} / \mathrm{g}$ \\
\hline 1 & slag & 0.3 & 1200 & \multirow{2}{*}{4000} \\
\hline 2 & limestone & 0.3 & 1200 & \\
\hline
\end{tabular}

Before conducting research, it is necessary to prepare the initial (traditional) backfill mixture with the specific surface area of the binding material particles, which is used in the backfilling technology. For this purpose, granulated blast-furnace slag is ground in a laboratory Ball Mill to a fineness of $55 \%$ of particles with a coarseness of $0.074 \mathrm{~mm}$, which corresponds to the fineness of grinding in production mills of the backfilling complex and is also equivalent to a specific surface area of $2000 \mathrm{~cm}^{2} / \mathrm{g}$.

Backfill mixtures are prepared: No.1 (at $S_{\text {spec }}=2000 \mathrm{~cm}^{2} / \mathrm{g}$ ), № 2 (at $S_{\text {spec }}=4300 \mathrm{~cm}^{2} / \mathrm{g}$ ), and 12 samples of the hardening backfill mixture are poured in for strength testing at the hardening age of 30 and 90 days, 3 samples for each period of hardening. In the test compositions of the hardening backfill mixture, 50\% of the blastfurnace slag is replaced with ground flux waste of similar dispersion.

The test backfill mixtures are prepared beginning with the calculation of the components consumption for a 9-liter container, sufficient for filling 6 cubes-samples of the backfill material per one composition. Using one mixed composition, the backfill mixture samples are made for strength testing at the age of 30,90 and 180 days (selectively). First, crushed rock is added to the container, then - waste of flux with blast-furnace slag, and all is mixed in dry form. Then the dry mixture is tempered with water and mixed for 10 minutes. After mixing, the backfill mixtures are examined for adhesion, mobility, ultimate shearing stress.

The mixture mobility is determined using a StroyTSNIL cone device. The depth of the cone immersion in the backfill mixture is 
measured. The amount of water is added to the container with dry components according to the water flow rate $\left(350-4001 / \mathrm{m}^{3}\right)$, so that the mobility is in the range $10-12 \mathrm{~cm}$. The shearing stress value is determined by the Sternbek device. The effort of the moment is recorded when the pipeline section begins to displace relative to the mixture. The shearing stress value of the mixture should be no more than $1.96 \mathrm{MPa}$. The velocity of setting the mixture is determined using the Vicat apparatus. The depth of the needle immersion in the backfill mixture is measured $(\mathrm{cm})$. Setting of the backfill mixture should happen no earlier than after 4 hours.

After determining the technological parameters, each composition of the backfill mixture is poured into metal moulds with size of $10 \times 10 \times 10 \mathrm{~cm}$. The cassettes with the moulds are lubricated with technical oil in order to prevent the backfill mixture adhesion to the metal mould surface. In a day, the surfaces of the backfill mixture samples of each composition are numbered. The hardening backfill mixture is settled in the moulds for 3-4 days until complete loss of setting and complete drainage of water from the sample. Then, the moulds are dismantled, and backfill mixture samples are placed in special storage racks. The samples are placed in wet wood dust with a moisture content of about $90 \%$ and a temperature of $22-26{ }^{\circ} \mathrm{C}$ to simulate underground conditions.

The uniaxial compression strength of the hardening backfill mixture is determined by crushing the samples in a hydraulic press at ambient temperature. The backfill mixture samples should be loaded in the press with a rate of 0.3-0.5 MPa. A press of the PSU-100 series with a strength scale of up to $10 \mathrm{MPa}$ is used. And in the case, when the strength of the backfill mixture exceeds the specified value, a press of PSU-120 series of up to $50 \mathrm{MPa}$ should be used. The following data are recorded: sample number; cross-sectional area $S$ (cm), measured by vernier calliper; breaking force value $F(\mathrm{H})$, which is fixed on the press scale. The sample strength is determined by dividing the breaking force value by the sample area.

The microstructure, as well as the phase and quantitative composition of the components of hardening backfill mixture and artificial stone are studied using scanning electron microscopy [19]. Using an electron microscope-microanalyzer REMMA-102-02, it becomes possible to obtain high-quality photographs of the shape of 
the studied samples structure at a magnification of $50 \mu \mathrm{m}$ (Fig. $2 a$ ). The built-in X-ray spectral microanalyzer makes it possible to measure the chemical composition of the hardening backfill mixture structural formations. The studied fracture surface of the hardening backfill sample is shown in Figure $2 b$.

$a$

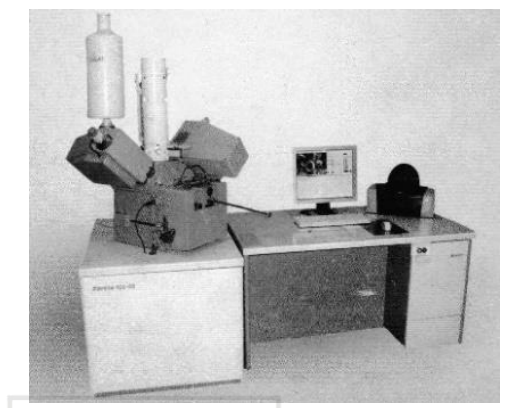

$b$

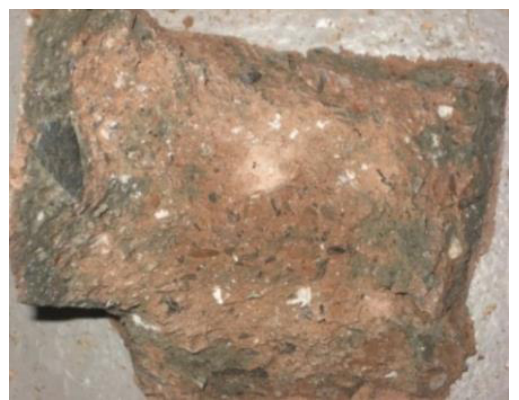

Fig. 2. Research into backfill mass microstructure: $(a)$ general view of the microscope-microanalyzer REMMA-102-02;

(b) fracture surface of the backfill mass sample

The shapes and sizes of the sample particles are studied, as well as the intergranular bonds formed during the backfill material hardening. Using the X-ray spectral microanalyzer, from 1 to 5 measurements of the quantitative composition of basic oxides $\mathrm{CaO}$, $\mathrm{SiO}_{2}, \mathrm{MgO}, \mathrm{Al}_{2} \mathrm{O}_{3}$, are performed in each sample. The procedure of measuring the chemical composition consists in examining the entire field of particles in the image to detect particle of a substance with different chemical composition or oxide content.

As a result of measurements, the oxide spectra are obtained, then the microscope software calculates these spectra and displays the percentage of oxides on the computer. The method is based on the determination of the electronic image contrasts by electron diffraction.

\section{Main part}

4.1. Theoretical foundations of the strong hardening backfill mass formation based on the fine-dispersed particles

For a reasonable choice of the hardening high-strength backfill composition when mining the reserves of iron ores, it is necessary to 
study the processes of chemical bonds structure formation under the influence of fine-dispersed fractions of a binding material. Therefore, the backfill material chemical composition is of significant importance, which either creates stable, strong bonds in the artificial mass or weakens them.

Crystallized blast-furnace slags, containing up to $4-6 \% \mathrm{MgO}$ and up to $5-10 \% \mathrm{Al}_{2} \mathrm{O}_{3}$, usually possess dicalcium silicate, rankinite and melilite with a predominant content of the helenite component. Slags are generally composed of $90 \%$ glass. In the crystalline form, the slags are not reactive, however, in the non-crystalline form, the ability to hydration is observed [20]. Blast-furnace granulated slag of the PJSC "ZaporizhzhiaStal", is in a glassy state caused by rapid cooling. It contains melilite and pseudowollastonite [21].

The main phase of the flux limestone chemical composition with a high content of $\mathrm{CaO}$ and low $\mathrm{MgO}$ is calcite, there are impurities of dolomite and wollastonite. The host rocks of the PivdennoBilozerske ore field are mainly represented by quartz-chloritesericite shales, which are delivered to dumps. Their chemical composition contains a whole group of minerals of the mica class. At a content of $25-30 \%$ iron, hematite is present in the composition of the rocks. Hydration of backfill material minerals complies with the general laws of mineral substances hardening, the strength of which depends on the formed chemical compounds, their composition and form.

Let us study the products of hydration in the backfill mass with the fineness of binding material grinding of $55 \%$ of particles with a coarseness of $-0.074 \mathrm{~mm}$. Slag minerals begin to exert binding properties during hydration. Calcarenite can also exert binding properties. When producing cement, $\mathrm{CaCO}_{3}$ is sometimes added as a microfiller to improve the physical and technical properties. On the other hand, limestone with a coarseness of up to $5 \mathrm{~mm}$ is fed to the backfill mixture, therefore, the share of fine particles is minimal, which cannot have a significant influence on strength.

Minerals of granulated blast-furnace slags, akermanite $\left(2 \mathrm{CaO} \cdot \mathrm{MgO} \cdot 2 \mathrm{SiO}_{2}\right)$, helenite $\left(2 \mathrm{CaO} \cdot \mathrm{Al}_{2} \mathrm{O}_{3}\right)$, which are part of melilite, as well as pseudowollastonite $\left(\alpha-\mathrm{CaO} \cdot \mathrm{SiO}_{2}\right)$, are in a glassy state. In the natural state they practically do not exert binding properties [22]. Over time, a gel-like mass of calcium hydrosilicates 
is formed on the surface of the mineral grains. When grinding the blast-furnace slag, the hydraulic activity of minerals increases. As it is noted in the work [23], with a specific surface area of 4000$6000 \mathrm{~cm}^{2} / \mathrm{g}$, slag minerals intensively exert hydraulic activity.

Under mechanical action on the blast-furnace slag particles, the freshly formed surface of the particle has a high reactivity caused by the surface energy accumulation. New freshly formed surfaces have significantly higher surface energy values, which leads to their increased adhesive activity. The special energetic state of the new surfaces of ground mineral materials - quartz, limestone, magnesite, gypsum, etc. - can be explained by the formation of a large number of non-saturated valence bonds. Thus, when quartz crystals are ground, as a result of breaking a significant amount of Si-O bonds, ions of $\mathrm{Si}^{4+}, \mathrm{O}^{2-}$ are formed on the surface of grains [24]. Water in the backfill mixture, when coming into contact with fractures and cavities of the surface of fine-dispersed slag particles, promotes the cations transfer from the surface to the state of solution due to the breaking of silicon-oxygen bonds [25].

The main oxides of the blast-furnace slag are $\mathrm{CaO}$ and $\mathrm{SiO}_{2}$, the content of which is $85 \%$ or more. In this case, in the structure of slag minerals, the predominantly ionic $\mathrm{Ca}-\mathrm{O}$ and covalent $\mathrm{Si}-\mathrm{O}$ bonds are destroyed. The energy of these types of bonds is 1075.6 and $1861 \mathrm{~kJ} / \mathrm{mol}$, respectively [22], which indicates a greater exposure of ionic $\mathrm{Ca}-\mathrm{O}$ bonds to destruction. It can be concluded that more calcium $\mathrm{Ca}^{2+}$ ions are formed on the surface of ground slag particles than $\mathrm{Si}^{4+}$ ions. In addition, the substance solubility increases with increa-sing dispersion. The remaining silica content is in the amorphous state. It follows from this that it is necessary to transform the contained silica from an amorphous state into an active one in order to increase its content in strong crystalline formations of the backfill mass.

In the process of hydration, a hydrosilicate gel will be formed with a predominance of a weak ionic $\mathrm{Ca}-\mathrm{O}$ bond in its structure. This explains the relatively low backfill mass strength of 5-6 MPa with a high consumption of blast-furnace slag $400-450 \mathrm{~kg} / \mathrm{m}^{3}$ and flux waste $1000-1100 \mathrm{~kg} / \mathrm{m}^{3}$ in the mixture composition.

As a result of melilite-like minerals hydration, a large number of gels and colloidal solutions are formed, and crystalline substances 
are almost completely suppressed. With coarse grinding of slag minerals, the basicity index will be $\mathrm{CaO} / \mathrm{SiO}_{2} \geq 1.5$. Therefore, an insufficient amount of activated silica is involved in the process of artificial mass structure formation. It can be concluded that the specific surface area of particles influences not only on an increase in the contacts number and the density of interaction between particles, but from the point of view of chemical concepts - also on the final basicity index of $\mathrm{CaO} / \mathrm{SiO}_{2}$, which determines the strength of crystalline formations. Under normal conditions, the hydraulically active phases of the slag slowly harden and are characterized by low strength [26].

Differences in the composition and morphology of hydrosilicate gels can be explained by unequal hydration conditions and unreacted calcium silicates, as well as by varying degrees of particle defectiveness during grinding. Consequently, with a grinding fineness of $55 \%$ of particles with a coarseness of $-0.074 \mathrm{~mm}$, the growth of crystal bonds will be rather slow. Due to the lower slag minerals activity, in comparison with minerals of Portland cement clinker, as well as the heterogeneity of particles after ball grinding when interacting with water, hydration will occur unevenly without oversaturation with ions. As a result, highly basic calcium hydrosilicates with a variable composition in a gel-like form are formed, which can be referred to the group C-S-H (II) (Fig. 3) [27, 28].

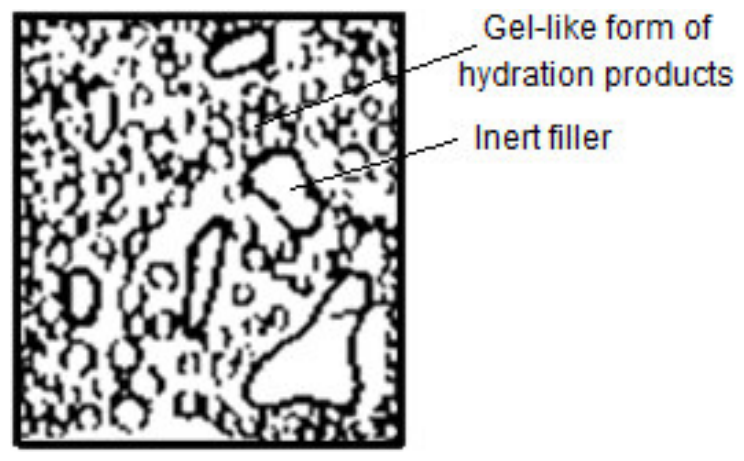

Fig. 3. Artificial stone structure containing highly basic calcium hydrosilicates 
If, during the clinker minerals hydration, the hydrosilicate gel remains for several days, then during the slag minerals hydration, this process is longer. The hydration products of slag minerals are similar to cement clinker, but differ in a lower content of $\mathrm{CaO}$ and $\mathrm{H}_{2} \mathrm{O}$ [25]. Gel (C-S-H) is similar in composition to tobermorite, therefore it is often called tobermorite-like.

Noticeable differences in morphology, as well as in X-ray diffraction patterns, make it possible to determine the difference between C-S-H (I) and C-S-H (II): C-S-H (I) with a ratio of $\mathrm{CaO} / \mathrm{SiO}_{2}<1.5$ is a laminate calcium hydrosilicate, and $\mathrm{C}-\mathrm{S}-\mathrm{H}$ (II) with a ratio of $\mathrm{CaO} / \mathrm{SiO}_{2}>1.5$ - is mainly fibrous calcium hydrosilicate $[29,30]$. With a high ratio of $\mathrm{CaO} / \mathrm{SiO}_{2}>2-3$, calcium hydrosilicates have a round particle shape and are formed in the form of a gel. Low-basic calcium hydrosilicates are presented in the form of $(0.8-1.5) \cdot \mathrm{CaO} \cdot \mathrm{SiO}_{2} \cdot(0.5-2.5) \mathrm{H}_{2} \mathrm{O}$, highly basic - (1.52) $\cdot \mathrm{CaO} \cdot \mathrm{SiO}_{2} \cdot(1-4) \mathrm{H}_{2} \mathrm{O}[31]$.

The mineral substances represented in the slag are hydration products, but their low activity, in comparison with cements, when interacting with water, forms highly basic hydrosilicate structures. Gel (C-S-H), in addition to aluminium, iron and sulphur, may contain small amounts of magnesium, sodium, potassium, as well as remains of titanium and chlorine [30]. Therefore, as a result of slag hydration, the calcium hydrosilicates contain oxides of $\mathrm{Al}_{2} \mathrm{O}_{3}, \mathrm{MgO}$, and $\mathrm{FeO}$.

With an increase in the fineness of grinding to $100 \%$ of particles $-0.074 \mathrm{~mm}$, all active slag minerals take part in hydration. If the share of particles with a coarseness of $-0.074 \mathrm{~mm}$ is $100 \%$ and flux limestone waste is added to the backfill mixture as a microfiller, then the amount of $\mathrm{Si}^{4+}$ ions will increase, and some of the ions of the weak $\mathrm{Ca}^{2+}$ bond will pass to the formation of tetracalcium monocarbonate hydroaluminate $3 \mathrm{CaO} \cdot \mathrm{Al}_{2} \mathrm{O}_{3} \cdot \mathrm{CaCO}_{3} \cdot 11 \mathrm{H}_{2} \mathrm{O}$. This will lead to equa-lizing the content of $\mathrm{Ca}^{2+} \approx \mathrm{Si}^{4+}$ ions in the backfill mixture and the formation during hardening of calcium hydrosilicates of fibrous and laminate types with low basicity (0.8- 
1.5) $\mathrm{CaO} \cdot\left(\mathrm{Al}_{2} \mathrm{O}_{3}, \mathrm{MgO}, \mathrm{FeO}\right) \cdot \mathrm{SiO}_{2} \cdot(0.5-2.5) \mathrm{H}_{2} \mathrm{O}$. Their structure is shown in Figure 4 [27].

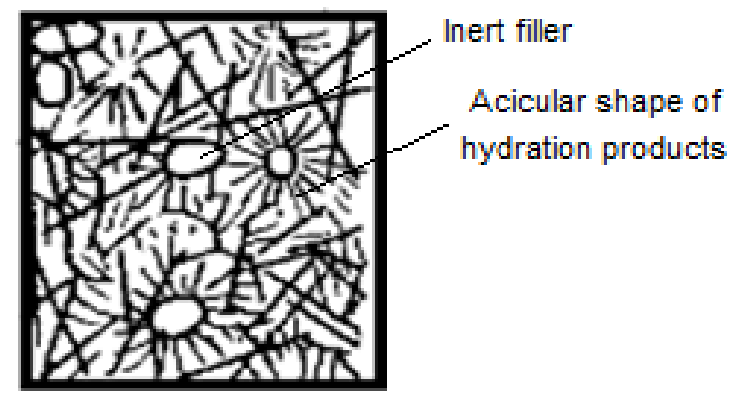

Fig. 4. Artificial stone structure containing low-basic calcium hydrosilicates

It follows from the above that for greater destruction of the $\mathrm{Si}-\mathrm{O}$ bonds number, it is necessary to increase the degree of particle dispersion, which will also increase the calcium silicate particles solubility. This is facilitated by the occurrence of microfractures and defects in particles during grinding. As a result, water is in contact with all surfaces. Consequently, a strong structure of calcium hydrosilicates is formed, which are more crystallized. A finer grinding of slag minerals will release more silicon ions, which will lead to the formation of strong covalent bonds in the hydrosilicate gel. According to some data, contribution of covalent bonds to the cement stone strength is about $65 \%$ [32].

As a result, conditions are created for the growth of various forms and structures of calcium hydrosilicates, which leads to an increase in strength. The finely ground share of the limestone, which contains $\mathrm{CaCO}_{3}$, exerts the ability to hydration. In this case, ground calcite will interact with water and the helenite share of melilite, which will lead to the formation of calcium hydrocarboaluminate, which helps to strengthen the artificial stone. As a result of balanced state in $\mathrm{Ca}-$ $\mathrm{O}$ and $\mathrm{Si}-\mathrm{O}$ bonds due to an increase in the breaking of $\mathrm{Si}-\mathrm{O}$ bonds under the action of fine grinding, calcium hydrosilicates of lower basicity $\mathrm{CaO} / \mathrm{SiO}_{2} \leq 1.5$ are formed.

The appearance of formed crystalline structures in the backfill stone has a positive effect on the strength of the artificial mass. 
Therefore, in order to increase the strength of the chamber backfill mass, it is necessary to create strong crystalline bonds in its structure by the time of mining the reserves of the second stage stope chambers. In the works [33, 34], it is indicated that the formation of low-basic calcium hydrosilicates increases the strength of the cement stone, but when highly basic hydrosilicates appear, its strength decreases.

\subsection{Experimental research on the strong hardening backfill mass formation based on the fine-dispersed particles}

As a result of grinding the granulated blast-furnace slag and flux limestone using the USI-20 unit, the actual value of the specific surface area of the particles is $4300 \mathrm{~cm}^{2} / \mathrm{g}$, with an assumed design value of $4000 \mathrm{~cm}^{2} / \mathrm{g}$, the deviation is $7 \%$. The rheological properties of the backfill mixtures №1 and №.2 have been studied. The average indicators of shearing stress are 0.85 and $0.74 \mathrm{MPa}$, mobility - 11.7 and $11.4 \mathrm{~cm}$, setting time -14.5 and 13 hours. These parameters satisfy the requirements for the backfill mixture transportation.

Three samples of each test mixture № 1 and № 2 are studied for strength at the age of 30 and 90 days of hardening. Photos of the procedure for determining the strength of backfill mass for uniaxial compression of the backfill mass samples are shown in Figure 5.
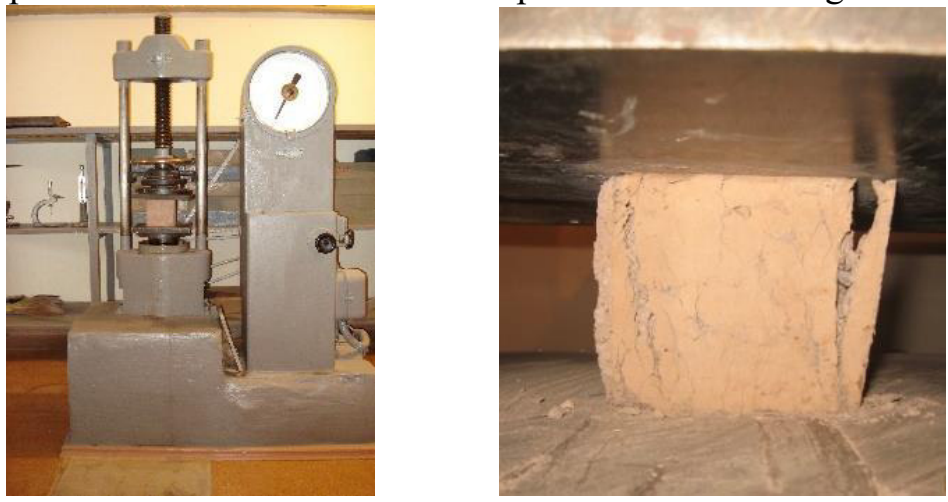

Fig. 5. Strength test of hardening backfill mass samples

Analysis of the histograms in Figure 6 shows a positive tendency to an increase in the backfill mass strength with a change in the specific surface area of the particles at the age of 30 and 90 days. At the age of 
30 days, the backfill mass strength increases by 2.5 times, and 90 days 1.7 times. An intensive increase in strength after 30 days is noteworthy, since the rock mass strength actually reaches the standard strength with an indicator of 7-8MPa for a mining depth of $640-940 \mathrm{~m}$.

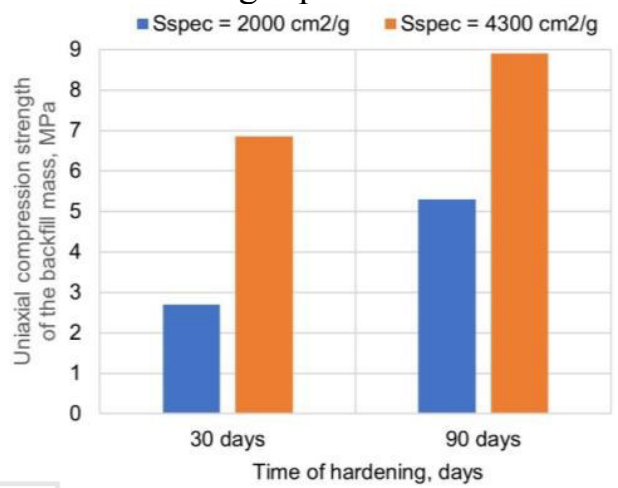

Fig. 6. Results of determining the uniaxial compression strength of the backfill mass

To confirm the theoretical assumptions of the blast-furnace slag and flux waste dispersion influence on the structure, shape and chemical composition of crystalline new formations of the backfill stone, the destroyed samples of the backfill mass with different specific surface areas of particles have been studied using scanning electron microscopy with a built-in X-ray spectral microanalyzer (Fig. 7).

$a$

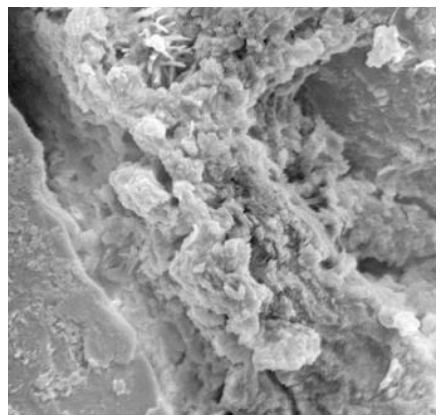

$b$

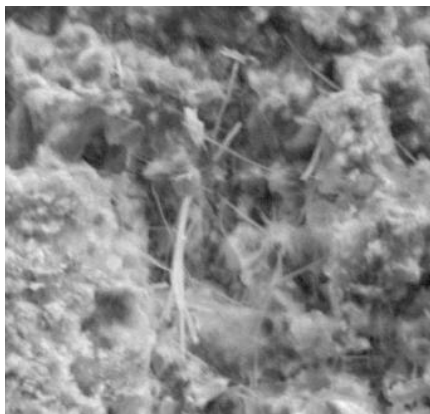

Fig. 7. Structural bonds development in the backfill mass with a change in the specific surface area: (a) at $2000 \mathrm{~cm}^{2} / \mathrm{g}$; (b) at $4300 \mathrm{~cm}^{2} / \mathrm{g}$ 
In the sample (Fig. 7a), two large filler particles are clearly observed, interconnected by weakly crystallized new formations of calcium hydrosilicate, which is in a gel-like state. Crystalline new formations have dense, round-indefinite shapes of particle with protruding disordered rare single needles and plates. Having such a structure, the mass cannot withstand tensile stresses arising on the backfill mass contour, which in practice occurs in conditions of the ore reserves development at the Pivdenno-Bilozerske field.

An increase in the specific surface area of particles of a binding material to $4300 \mathrm{~cm}^{2} / \mathrm{g}$ has significantly influenced on the structure formation of new formation (Fig. 7b). Calcium hydrosilicates have an acicular-fibrous and acute-angled shape, the particles are densely distributed in relation to each other, the porosity has decreased, the inert filler grains are completely covered with hydrate formations. Artificial stone is reinforced with crystalline new formations, hence adhesion forces and resistance of internal bonds to loads increase. The structure of the new formations acquires an acute-angled shape, replacing the round shape characteristic of the samples of the first and second series. The strength properties of the backfill mixture sample significantly increase, which is shown in Figure 6. In comparison with the No. 1 mixture samples, this one clearly demonstrates the dominant influence of the bonds form and their chemical composition. Forms of bonds in Figure 7 closely correlate with the forms in Figures 3 and 4 . The results of determining the structural bonds chemical composition of the mixture samples No. 1 and No. 2 are presented in Table 2.

Table 2

Results of chemical composition measurements

of the hardening backfill mass structural bonds

\begin{tabular}{|c|c|c|c|c|c|}
\hline \multirow{2}{*}{$\begin{array}{c}\text { Sample } \\
\text { of backfill mass }\end{array}$} & \multirow{2}{*}{$\begin{array}{l}S_{\text {spec }} \\
\mathrm{cm}^{2} / \mathrm{g}\end{array}$} & \multicolumn{2}{|c|}{$\begin{array}{c}\text { Oxide } \\
\text { content, } \% \\
\end{array}$} & \multirow{2}{*}{$\begin{array}{c}\text { Average } \\
\text { value } \\
\mathrm{CaO} / \mathrm{SiO}_{2}\end{array}$} & \multirow{2}{*}{$\begin{array}{l}\text { Form of new } \\
\text { formations }\end{array}$} \\
\hline & & $\mathrm{CaO}$ & $\mathrm{SiO}_{2}$ & & \\
\hline \multirow{4}{*}{ Mixture No. 1} & \multirow{4}{*}{2000} & 55.12 & 25.14 & \multirow{4}{*}{2.63} & \multirow{4}{*}{$\begin{array}{l}\text { Round, } \\
\text { indefinite }\end{array}$} \\
\hline & & 52.48 & 26.60 & & \\
\hline & & 49.68 & 26.63 & & \\
\hline & & 71.53 & 15.76 & & \\
\hline \multirow{3}{*}{ Mixture No. 2} & \multirow{3}{*}{4300} & 45.50 & 22.06 & \multirow{3}{*}{1.48} & \multirow{3}{*}{$\begin{array}{c}\text { Pyramidal, } \\
\text { acute-angled, } \\
\text { acicular-fibrous }\end{array}$} \\
\hline & & 31.16 & 34.18 & & \\
\hline & & 38.10 & 29.70 & & \\
\hline
\end{tabular}


The data in Table 2 show that with an increase in the specific surface area of the binding material particles, the basicity of the formed hydrosilicate bonds decreases, and the shape of the structural formations changes significantly. If with the basicity $\mathrm{CaO} / \mathrm{SiO}_{2}=2.63$, the highly basic calcium hydrosilicates with a round, pyramidal, thick- acicular structure are formed, then with $\mathrm{CaO} / \mathrm{SiO}_{2}=1.48$ - the low-basic calcium hydrosilicates with a pronounced acicular-fibrous structure. This also explains the significant difference in the intensity of strength growth both at 30 and 90 days of the mixture hardening.

According to the measurements of $\mathrm{CaO}$ and $\mathrm{SiO}_{2}$ in the № 1 and No. 2 test backfill mixtures with various degrees of specific surface area of the binding material particles, using the positions of deriving the true formulas, the newly formed calcium hydrosilicates can be described by the following formulas

$$
\begin{array}{ll}
2.63 \mathrm{CaO} \cdot \mathrm{SiO}_{2} \cdot \mathrm{H}_{2} \mathrm{O} & \text { at } S_{\text {spec }}=2000 \mathrm{~cm}^{2} / \mathrm{g} \\
1.44 \mathrm{CaO} \cdot \mathrm{SiO}_{2} \cdot 1.76 \mathrm{H}_{2} \mathrm{O} & \text { at } S_{\text {spec }}=4300 \mathrm{~cm}^{2} / \mathrm{g} .
\end{array}
$$

Thus, the basic principles of the structure formation of the backfill mass in relation to the strength characteristics with an increase in the dispersion of the binding material particles have been studied in the work. This makes it possible to control these parameters depending on the value of the stress field acting on the backfill mass when extracting the iron ore from the subsoil.

\section{Conclusions}

The issues of creating a strong backfill mass with internal bonds resistant to loads are important for mining enterprises that backfill underground cavities with hardening mixtures. The interaction and products of hydration of the backfill mixture components with water have been studied. It has been determined that with an increase in the specific surface area of the binding material particles, the new formations shape of the backfill mass improves, it has high strength, and the basicity of its new formations is capable of changing. This is caused by a large gap in the covalent bonds of silica with a more intense grinding of the binding material, as well as the transition of ions of a weak ionic bond to the formation of other compounds and equalizing the ratio of $\mathrm{Si}$ and $\mathrm{Ca}$ ions in solution. 
There is a positive tendency towards an increase in the backfill mass strength with a change in the specific surface area of particles from 2000 to $4300 \mathrm{~cm}^{2} / \mathrm{g}$ at the age of 30 and 90 days. At the age of 30 days, the backfill mass strength increases by 2.5 times, and 90 days - 1.7 times. It has been determined that with an increase in the specific surface area of the binding material particles, the basicity of the formed hydrosilicate bonds decreases, and the structural formations shape changes significantly towards their strengthening from gel-like to acicular-fibrous.

The research data on the composition and shape of structural bonds at a certain strength of the hardening backfill mass will make it possible to rationally choose the dispersion, obtain high strength of the backfill mass and increase the stability of the artificial mass outcropping.

\section{References}

1. Derzhavna fiskalna sluzhba Ukrainy. (2019). Ofitsiinyi portal. Rezhym dostupu http://sfs.gov.ua/

2. Shatokha, V. (2015). The sustainability of the iron and steel industries in ukraine: challenges and opportunities. Journal of Sustainable Metallurgy, 2(2), 106115. https://doi.org/10.1007/s40831-015-0036-2

3. Bazaluk, O., Petlovanyi, M., Lozynskyi, V., Zubko, S., Sai, K., \& Saik, P. (2021). Sustainable underground iron ore mining in Ukraine with backfilling worked-out area. Sustainability, 13(2), 834. https://doi.org/10.3390/su13020834

4. Pysmennyi, S.V., \& Brovko, D.V. (2018). Zberezhennia richnoi produktyvnosti shakht Kryvorizkoho zalizorudnoho baseinu pry vidpratsiuvanni zaliznykh rud na velykykh hlybynakh. Visnyk Kryvorizkoho Natsionalnoho Universytetu, (46), 164-168.

5. Azaryan, A.A., Batareyev, O.S., Karamanits, F.I., Kolosov, V.O., \& Morkun, V.S. (2018). Ways to reduce ore losses and dilution in iron ore underground mining in Kryvbass. Science and Innovation, 14(4), 17-24. https://doi.org/10.15407/scine14.03.017

6. Khomenko, O., Kononenko, M., \& Myronova, I. (2017). Ecological and technological aspects of iron-ore underground mining. Mining of Mineral Deposits, 11(2), 59-67. https://doi.org/10.15407/mining11.02.059

7. Petlovanyi, M.V., \& Ruskykh, V.V. (2019). Peculiarities of the underground mining of high-grade iron ores in anomalous geological conditions. Journal of Geology, Geography and Geoecology, 28(4), 706-716. https://doi.org/10.15421/111966 
8. Hrinov, V.H., \& Khorolskyi, A.O. (2020). Studies of the basics of technology for optimal design of rational use of valuable mineral deposits. Mineral Resources of Ukraine, (2), 19-24. https://doi.org/10.31996/mru.2020.2.19-24

9. Shashenko, O.M., Hapieiev, S.M., Shapoval, V.G., \& Khalymendyk, O.V. (2019). Analysis of calculation models while solving geomechanical problems in elastic approach. Naukovyi Visnyk Natsionalnoho Hirnychoho Universytetu, (1), 28-36. https://doi.org/10.29202/nvngu/2019-1/21

10. Petlovanyi, M.V., Zubko, S.A., Popovych, V.V., \& Sai, K.S. (2020). Physicochemical mechanism of structure formation and strengthening in the backfill massif when filling underground cavities. Voprosy Khimii i Khimicheskoi Technologii, (6), 142-150. https://doi.org/10.32434/0321-4095-2020-133-6-142-150

11. Bitimbaev, M.Zh., \& Krupnik, L.A. (2012). Teoriya i praktika zakladochnykh rabot pri razrabotke mestorozhdeniy poleznykh iskopaemykh. Almaty: Mir, $600 \mathrm{~s}$.

12. Kuz'menko, A.M., \& Petlevanyy, M.V. (2017). Razrushenie zakladochnogo massiva $\mathrm{v}$ zavisimosti ot tekhnologii ego vozvedeniya. Zbirnyk Naukovykh Prats NHU, (52), 159-166.

13. Wu, J., Feng, M., Mao, X., Xu, J., Zhang, W., Ni, X., \& Han, G. (2018). Particle size distribution of aggregate effects on mechanical and structural properties of cemented rockfill: Experiments and modeling. Construction and Building Materials, (193), 295-311. https://doi.org/10.1016/j.conbuildmat.2018.10.208

14. Petlovanyi, M., \& Mamaikin, O. (2019). Assessment of an expediency of binder material mechanical activation in cemented rockfill. ARPN Journal of Engineering and Applied Sciences, (14), 3492-3503.

15. Zhang, B., Xin, J., Liu, L., Guo, L., \& Song, K.-I. (2018). An experimental study on the microstructures of cemented paste backfill during its developing process. Advances in Civil Engineering, (2018), 1-10. https://doi.org/10.1155/2018/9783046

16. Kuz'menko, A.M., \& Petlevanyy, M.V. (2013). Formirovanie zakladochnogo massiva na osnove tonkodispersnykh chastits vyazhushchikh materialov pri podzemnoy razrabotke rudnykh mestorozhdeniy. Metallurgicheskaya i Gornorudnaya Promyshlennost', (2), 70-73.

17. Kuz'menko, A.M., Petlevanyy, M.V., Chistyakov, E.P., \& Kulish, S.A. (2009). K voprosu podbora sostava tverdeyushchey zakladki povyshennoy prochnosti Sbornik Nauchnykh Ttrudov NAN Ukrainy, (82), 50-57.

18. Gorobets, L.Zh., Kovalenko, V.V., \& Pryadko, N.S. (2009). Uprochnenie stroitel'nykh materialov pri obrabotke v struyakh. Dynamika ta Mitsnist Mashyn, Budivel, Sporud, 3(25), 59-66.

19. Gouldsteyn, D., Nyuberi, D., \& Echlin, P. (1984). Rastrovaya elektronnaya mikroskopiya i rentgenovskiy mikroanaliz. Moskva: Mir, 303 s. 
20. Togobitskaya, D.N., Khamkhot'ko, A.F., \& Stepanenko, D.A. (2009). Otsenka kristallizatsionnoy sposobnosti i mineralogicheskogo sostava konechnykh domennykh shlakov v syr'yevykh i tekhnologicheskikh usloviyakh domennykh pechey zavodov Ukrainy. Fundamental'nye i Prikladnye Problemy Chernoy Metallurgii, (20), 54-60.

21. Kulik, V.A., Saley, A.A., \& Kravchenko, T.V. (2004). Optimizatsiya sostavov zakladochnykh smesey. Analiz khimiko-mineralogicheskogo sostava i fiziko-tekhnicheskikh pokazateley shlakov Donetsko-Pridneprovskogo regiona. Voprosy Khimii i Khimicheskoy Tekhnologii, (2), 54-60.

22. Butt, Yu.M., Sychev, M.M., \& Timashev, V.V. (1980). Khimicheskaya tekhnologiya vyazhushchikh materialov. Moskva: Vysshaya shkola, $472 \mathrm{~s}$.

23. Ramachandran, V.S. (1988). Dobavki v beton. Moskva: Stroyizdat, 575 s.

24. Kingeri, U.D. (1987). Vvedenie v keramiku. Moskva: Stroyizdat, $500 \mathrm{~s}$.

25. Royak, S.M., \& Royak, G.S. (1983). Spetsial'nye tsementy. Moskva: Stroyizdat, 279 s.

26. Dvorkin, L.I., \& Dvorkin, O.L. (2007). Stroitel'nye materialy iz otkhodov promyshlennosti. Rostov-na-Donu: Feniks, 368 s.

27. Teylor, Kh. (1996). Khimiya tsementa. Moskva: Mir, $560 \mathrm{s.}$

28. Hu, C., Ruan, Y., Yao, S., Wang, F., He, Y., \& Gao, Y. (2019). Insight into the evolution of the elastic properties of calcium-silicate-hydrate (C-S-H) gel. Cement and Concrete OV Composites, OV/(104), B al 103342. https://doi.org/10.1016/j.cemconcomp.2019.103342

29. Kuznetsova, T.V., Kudryashov, I.V., \& Timashev, V.V. (1989). Fizicheskaya khimiya vyazhushchikh materialov. Moskva: Vysshaya shkola, $384 \mathrm{~s}$.

30. Kazanskaya, E.N. (1990). Obrazovanie gidratnykh faz portlandtsementnogo kamnya. Leningrad: Znanie, $50 \mathrm{~s}$.

31. Gorshkov, V.S., Timashev, V.V., \& Savel'yev, V.G. (1981). Metody fiziko-khimicheskogo analiza vyazhushchikh veshchestv. Moskva: Vysshaya shkola, $335 \mathrm{~s}$.

32. Brykov, A.S. (2008). Gidratatsiya portlandtsementa. Sankt-Peterburg: Mir, $30 \mathrm{~s}$.

33. Khayrutdinov, M.M., \& Votyakov, M.V. (2007). Vybor khimicheskikh dobavok dlya tverdeyushchey zakladki na kaliynykh rudnikakh. Gornyi Informatsionno-Analiticheskiy Byulleten', (6), 218-220.

34. Domokeev, A.G. (1989). Stroitel'nye materialy. Moskva: Vysshaya shkola, $494 \mathrm{~s}$. 